kancellár. De Albert nagymester, majd porosz herceg fivérei, Kázmér vagy György is fontos információs csatornának számítottak, hol több, hol kevesebb lengyel-porosz szempontból értékes információt továbbítva. Vagyis az itt közölt források akarva-akaratlan is egy, ha nem több szürőn át mutatják a legjelentősebb cseh-magyar, bel- és külpolitikai fejleményeket, amit feltétlenül érdemes észben tartani a források elemzésekor. Kérdés, hogy csak ezek alapján valóban érdemes-e, el lehet-e beszélni az oly sokszor megírt négy év egyébként is kusza politikatörténetét, ahogy arra a források szerkesztője igen terjedelmesre nyúlt bevezetőben kísérletet tesz (6-59.). Anélkül, hogy e korlátokat figyelembe venné, illetve hogy az ezen évek politikai-hadi történéseivel foglalkozó német vagy más nyelvü szakirodalmi termés egyetlen darabjával komolyan ütköztetné megállapításait. Nem inkább arra szolgálnak e levelek forrásul, hogy miről volt tudomásuk a levélíróknak, egészen pontosan: mit (nem) akartak a levelezöpartnerükkel megosztani, hogy hogyan kívánták őt befolyásolni? Voltaképpen az efféle módon felhalmozódott hír- és levelezésgyüjteményekkel kapcsolatban e kérdésekre, az információáramlás (Kelet-)Közép-Európában még mindig nem szisztematikus igénnyel tisztázott rendszerére lennének legmegfelelőbbek e források - természetesen a hasonló, Bécsben, London, Varsóban vagy másutt őrzött anyaggal való szigorú összevetés után.

Különösen érdekesek a levélmellékletek: gondolok itt arra a feljegyzésre, amely az 1526. évi rákosi országgyülés határozatait tartalmazza (Nr. 89) vagy éppen a mohácsi halottak listájára (Nr. 115/3), amelynek példányai Európa-szerte fennmaradtak levél- és kézirattárakban. De Sárffy Ferencnek a magyar fordítása révén a nagyközönség számára ismert, 1526 októberében keletkezett levelét is megtaláljuk korabeli másolat formájában Berlinben (Nr. 115/7). (E két utóbbi a már említett Szydłowiecki egy-egy 1526 novemberében kelt levelének mellékletét képezte.) A forrásgyüjtésnek talán a legunikálisabb darabjai kerültek színes másolatként a belső borítóra. Egyrészt egy a Magyar Királyság Budától délre eső részeit (Nr. 1) ábrázoló térkép a legfontosabb folyókkal és településekkel. Ez utóbbiak közül a részben védelmi szempontból legfontosabb települések kaptak helyet a térképen, vagy éppen azok, amelyek a hadi utánpótlás szempontjából elsődlegesek voltak (a Duna menti hadi út települései.) A térkép minden bizonnyal (nem sokkal) Nándorfehérvár eleste előtt készülhetett, de legalábbis az azelőtti állapotokat tükrözheti, mert még magyar kézen lévőnek mondják a várost és várat. Szintén egyedi találat az eddig csak müncheni példány nyomán ismert ülésrend (Nr. 285/3), amely Habsburg Ferdinánd 1527. évi székesfehérvári királykoronázása után tartott lakomához kapcsolódik, és amelyet először Iványi Béla talált meg, majd azt az újrafelfedezése után részletekbe menően Pálffy Géza hasznosította és tette közzé. Ez utóbbi munkát Gahlbeck különben nem ismeri, ahogy sajnos Kasza Péter Lanckorońska nyomán Berlinből is merítő Brodarics-okmánytára is hiányzik a felhasznált szakirodalomból, amely viszont napjainkban már a világhálón is elérhető. Az okmánytár összeállítója máskor viszont citál magyar szakirodalmat (ha nem is sokat), e téren azonban esetlegesség figyelhetö meg.

Az elmondottak alapján és különösen az internet korában joggal róható fel a munkával kapcsolatban az, hogy valójában minden igyekezet ellenére a kontextusba helyezés nem igazán sikerült: fájó pont a szakirodalmi beágyazottság hiánya, vagy például annak elmulasztása, hogy az itt felsorakoztatott források miként képezték egy nagy közép-európai híráramlat részét. E bosszantó elemek ellenére azonban az okmánytár összeállítójának teljességre való törekvéséért mégis hálásak lehetünk. S csak bízhatunk abban, hogy az elkövetkező évek hasonló vonatkozású iratanyaga egy újabb kötet formájában - a fentebb hiányolt ,típushibák" nélkül - minél hamarabb az érdeklődők számára is elérhetővé válik.

Péterfi Bence

Német-magyar kulturális szótár, Szász, sváb, landler, cipszer és bukovinai német nyelvü kultúra a történelemben és mindennapokban, szerk. Balogh F. András, Sepsiszentgyögy, 
Anyanyelvápolók Erdélyi Szövetsége, T 3 Kiadó nyomdája, 2017 (= Kulturális szótárak), $164 \mathrm{p}$.

A Balogh F. András összeállította kötet hatalmas ismeretanyagot dolgoz fel, mutat be közérthető és olvasmányos módon. Magyarázatai rendkívül informatívak a németül nem olvasó, szélesebb érdeklődő közönség számára. Bár az anyaggyüjtésben voltak az egyes szakterületekre vonatkozó munkában (zenetudomány, nyelvészet, irodalomtörténet, történettudomány, a természettudományok terén a botanikát és az orvostudományt említi meg) szakértő társai, akiknek előszavában köszönetet is mond; egy, a tudomány és a kultúra ilyen széles spektrumát átfogó, ennyi területre kiterjedő kulturális szótár természetesen nem lehet hiánytalanul teljes. Ennek oka az - ahogy előszavában is leszögezi -, hogy maga a szótárkészítő jelölte ki munkája határait, ő hozta meg döntéseit, mi az, ami a szótár tárgyát képezi, és mit kell kihagynia.

A kulturális szótár összeállítójának célja reprezentatív kép kialakítása a tárgyalt terület kultúrájáról, jelenségeiről, történetéről. Mint írja: a világhálón megtalálható fogalmakhoz képest a szótár annyiban nyújt többet, hogy magyarázatokat, bizonyos esetekben értékeléseket is füz a szócikkekben tárgyalt személyekhez, eseményekhez, jelenségekhez.

Ha összevetjük a hasonló különböző idegen és magyar nyelvü kulturális szótárakkal, a Bart István készítette, több kiadást megért angolmagyar, valamint a szintén tỏle származó amerikai-magyar, vagy Györffy Miklós német-magyar kulturális szótárához képest a szerző az alapvetően nyelvészeti indíttatású szótáraknál jóval nagyobb merítésre vállalkozik, a szellemi-kulturális élet egészét kívánja átfogni, és szótárformába szerkesztett kultúrtörténeti, országismereti kézikönyvet kíván létrehozni. A nagy különbség a fentebb említett munkák és Balogh F. András kötete között az, hogy míg az előbbiek a távolabbi országok kultúrtörténeti-országismereti hatásainak nyelvi lecsapódásait öntötték szótári formába, utóbbi a történelmi Magyarország és azon belül is hangsúlyosan
Erdély területébe betagozódott németség kultúrtörténeti hozadékát teszi lexikonszerüen közkinccsé. Ily módon az alcím többet árul el a kötet valódi tartalmáról, mint a semmitmondó német-magyar kulturális szótár cím. Ezáltal a német anyaország, vagy az Osztrák-Magyar Monarchia közös kultúrkincse Magyarország más területeit érintő hatása felvállaltan nem tartozik az itt tárgyalt munka témái közé.

A kötetet bevezető előszavában Balogh $\mathrm{F}$. András rendkívül alaposan bemutatja a Kárpát-medencében élö, a Szent Istvánt követő évszázadok során betelepített németség történetét, ezen belül egyes ismert kortárs személyek sorsát a kitelepedéssel/kitelepítéssel, illetve külföldön újra kezdett pályafutásuk ívének megrajzolásával követi végig.

A munka hangsúlyosan Erdélyre, mint a német-magyar együttélés egyik évszázadokon át létezett, jól körülhatárolható helyszínére összpontosít, nagyon sok történeti, helytörténeti, irodalomtörténeti és néprajzi forrás áll a szótárkészítő rendelkezésére, s Erdélyben felnővén, sok helyszínt módja is volt megtekinteni, ami számos alkalommal érződik a leírások élményszerü, személyes hangvételén. Ha a történelmi Magyarország egész területe képezné a magyar és a német kultúra összefonódásai vizsgálatának tárgyát, sokkal átfogóbb képet kaphatnánk a szélesebben vett régió (Kelet-Közép- és Dél-Európa) német kultúrájáról. Ha azonban munkája pusztán Erdélyre terjed ki, ezt a címben kellett volna egyértelmübben kifejezésre juttatni.

A kötet szerkesztőjének kitüntetett figyelme az irodalom mellett a néprajz, valamint a szász müemlékek és zenei élet bemutatására irányul. És ez az ilyen egyszemélyes vállalkozások fő problémája is egyben, a válogatás esetlegessége. Több, különféle kutatási területről érkező munkatárs szisztematikusan tudta volna felgyüjteni az adott kutatási terület szótári címszóra érdemes témáit.

Természetesen nem célom minden hiányosság számba vétele, csak megjegyzem, hogy a sajtóval kapcsolatos szócikkek között az egyes városok jelentősebb újságainak felsorolása már szaklexikon feladata lenne, de mivel több eset- 
ben mégis találkozunk a kötetben valamilyen szempontból fontosnak, érdekesnek ítélt periodikumok bemutatásával, a meghatározó jelentőségü és tartalmas Temesvárer Zeitung (18521949) - véleményem szerint - mindenképpen megérdemelte volna a szótárba való felvételt.

A kötet végére illesztett bibliográfiából nagyon hiányzik Gerhard Sewann németül és magyarul is megjelent, a magyarországi németek történetét 1860-tól 2006-ig feldolgozó kétkötetes, hatalmas munkája.

A szótárat záró „Témakörök szerint rendezett szó- és névmutató"-hoz, amely az abc-be rendezett német szavakat, kifejezéseket adja meg magyarul, mindképpen hasznos lett volna az egyes szócikkek előfordulásának oldalszámait is hozzáfüzni, ami természetesen megnövelte volna a munkát, viszont könnyebbé tette volna a visszakeresést a könyvben. A témakörök szerinti névmutató alfejezetei: írók, költők, irodalmi múvek és irányzatok, sajtó, nyomdászat, könyvtárak, múzeumok, a tudományos kutatás forrásai, a természet, tájak, folyók, növények, építészet, müemlékek, a zene, kórusok, zeneszerzők, egyházak, vallás, vallási mozgalmak, vallási vezetők, intézmények, egyesületi szervek, érdekképviseletek, hiedelem- és mondavilág, hétköznapi élet, szokások, tánc, viselet, állattartás, növénytermesztés, lakberendezés, ételek, italok, népcsoportok, népnevek, nyelvjárások és azok kutatói, oktatás és müvészet, kortárs közélet és annak eseményei, települések nevei, valamint a történelmi események és fogalmak még egyszer főbb tematikus csoportok köré rendezve összegzik a kötetben szereplő szócikkeket. Az eligazodást mindenképpen megkönnyítette volna a névmutatóban a települések neveinél az adott helységet nem kétszer szerepeltetni, hanem a leírás tényleges helyére vonatkozó utalók (pl. Csatád $\rightarrow$ Lenauheim, ami a föszövegben igen helyesen így történt) alkalmazása, valamint a helységneveket a történetileg használt valamennyi nyelven ismételten meg kellett volna adni, annak ellenére, hogy magában a szótárban már szerepeltek.

Az összeállítás nemcsak érdekes és a tájékozódást segítő kézikönyv, de az oktatásban is haszonnal forgatható. Kritikai észrevétele- immel semmiképpen sem a szerkesztő-szerző munkáját akarom lebecsülni, mindössze azt a véleményemet kívántam rögzíteni, hogy egy ilyen nagy volumenü munka elvégzéséhez egy személy kevés. A kötet átdolgozásra feltétlenül érdemes. Kibővítése, az egyes, főleg történeti témakörök elmélyítése (mert az aktualitásokkal, a régió kortárs írói, mủvészei sorsának alakulásával kapcsolatban Balogh F. András nagy jártasságról tesz tanúbizonyságot), és a vizsgálódás földrajzi határainak kiterjesztése mindenképpen javasolható, s a részterületek szakkutatóinak bevonásával, a gyűjtő-feltáró munkát végzők teammé alakításával a könyv népszerüsítő jellegüből tudományos igényüvé válhatna.

RÓZSA MÁRIA

\section{Bogáti Fazakas Miklós históriás énekei és bibliai parafrázisai (Énekek éneke, Mózesi diadalversek, Jób könyve), 1575 - 1598, sajtó alá rendezte Ács Pál, Etlinger Mihály, Pap Balázs, Szatmári Áron, Szentmártoni Szabó Géza és Zsupán Edina, Budapest, Balassi Kiadó, 2018 (Régi Magyar Költők Tára XVI. századbeli magyar költők múvei, új folyam, sorozatszerk. Szentmártoni Szabó Géza, XIII/A), 502 p.}

A bemutatott kötetet kézbe véve a recenzens először is arról a jóleső érzésről adhat számot, hogy a magyar irodalmi mủvek kritikai kiadásának történetében hamarosan a régi magyarországi irodalom múvelői is elérnek arra a pontra, amelyre Arany János munkásságával foglalkozó kollégáik 2015-ben érkeztek meg: egy nagy munkafolyamat befejeződik, hogy aztán a mára elavult kötetekkel, amelyek esetünkben még a 19. században láttak napvilágot, újra lehessen kezdeni.

A kötet sajtó alá rendezőit kivétel nélkül az elvégzett munkáért járó hála és dicséret szavai illetik meg. Bogáti Fazakas Miklós munkái kritikai kiadásának jelen első, XIII/A kötete ugyanis egy alapos mủveltségü, sajátos világnézetủ írói személyiséget tár elénk, akinek életét és munkásságát nagy fokú reflektáltság jellemezte, amely, úgy tűnik, kiterjedt az általa 